\title{
Factors Related to Academic Stress During the Covid-19 Pandemic in Nursing Students of UPN Veteran Jakarta
}

\author{
Mareta Dea Rosaline $^{1^{*}}$, Diah Tika Anggraeni
}

\begin{abstract}
${ }^{I}$ Nursing Study Program, Faculy of Health Science, UPN Veteran Jakarta, Indonesia
${ }^{2}$ Nursing Study Program' Faculy of Health Science, UPN Veteran Jakarta, Indonesia

*Corresponding author. Email: maretarosaline@upnvj.ac.id
\end{abstract}

\begin{abstract}
Background: Academic stress is one of the biggest health problems that have an impact on academic performance. Students become a group that is vulnerable to the stress that comes from academic life. Academic stress that is usually experienced by students is due to academic responsibility. The online learning system that has changed during the Covid-19 pandemic requires students to get more assignments and a busy lecture schedule. Method: This study used a cross-sectional study design. The respondents were 175 students using the accidental sampling technique. The instrument used was a questionnaire consisting of demographic data and a statement regarding the level of academic stress with the modified Depression Anxiey and Stress Scale 42. Result: From the results of statistical tests, it was found that most of the respondents had a moderate stress level (34.3\%), the variable age value p-value $=0.001$, college load $\mathrm{p}$-value $=0.045$, achievement index $\mathrm{p}$-value $=0.302$, and residence status $\mathrm{p}$-value $=$

0.166. Conclusion: So that there is a relationship between age and study load with academic stress on students. Students who cannot adapt to environmental changes will result in impaired ability to adapt to stressors received from the academic process.
\end{abstract}

Keywords: academic stress, age, college load, nursing students

\section{INTRODUCTION}

The COVID-19 pandemic has made many parties try to overcome the spread of both the government and all society (Setiawan, 2020). One of the efforts made by issuing an online learning policy to prevent the spread of COVID-19 through the Minister of Education and Culture Circular No 36962 / MPK.A / HK / 2020 [1].This condition requires lecturers to do the process online or online. Online learning is a technology-based learning model through distance learning by using internet network facilities to interact online. Some of the advantages of the decision of the Minister of Education of the Republic online learning media are that they can increase learning interactions, facilitate learning interactions anywhere and anytime, have a wider reach, and facilitate the improvement and storage of learning materials [3].

Currently, universities in Indonesia apply strict rules to maintain the quality of graduates related to student study time limits; these rules are used based on of Indonesia Number 44 of 2015 part 4 of article 16, paragraph 1 letter, regarding the period and college load educational program for a maximum of seven academic 
years for undergraduate programs with a student study load of at least 144 Semester Credit Units (SKS). Students who cannot complete their studies within the stipulated time will receive a sanction, namely dropping out [2]. Students must complete lecture assignments from lecturers, field assignments/field practice, midterm, and final semester exams and write final projects to achieve this. Apart from academic problems, students also have issues studying, time management, and even lack of family support or being away from family. Family support is when experiencing pain, someone will seek permission from people around them to help and revive enthusiasm and self-confidence in the face of difficulties that are being experienced [3].

The responsibilities and demands of academic life and the many problems faced by students can be part of the stress commonly experienced by students. The

number of students experiencing academic stress increases each semester. The stress most commonly experienced by students is academic stress. Academic stress is mental stress related to frustration with academic failure, fear of failure, and even awareness of loss [4]. Students experiencing academic stress can have a positive or negative impact. Stress loads that are considered too heavy can lead to memory problems, concentration, decreased problem-solving abilities, and academic abilities [3]. Stress that is deemed heavy can also trigger health problems such as depression and excessive anxiety [5].

Stress has become a part of student academic life due to various internal and external factors that burden students. Students are particularly prone to academic stress problems when transitions occur on an individual and social level. Therefore, it becomes essential to understand the sources and impacts of academic stress to develop an adequate and efficient intervention strategy [6]. Previous research conducted by Karaman et al. [7] found that motivation support, life satisfaction, and place to live were significant predictors of academic stress in college students. Another study conducted on regular students of the DIII Nursing Cirebon study program, the Health Polytechnic of the Ministry of Health, Tasikmalaya with a sample size of 74 respondents, showed a significant relationship between age and the level of academic stress in students [8].Based on a preliminary study conducted on 15 nursing students, it was found that students complained of stress due to $30 \%$ piling up on college assignments so that students did not have enough time to rest, often experienced headaches, and decreased appetite, besides that some were afraid of the achievement index fell. $25 \%, 15 \%$ less cohesive group friends, $10 \%$ experiencing personal problems, and $20 \%$ being far from family. This study aimed to determine the factors related to the level of academic stress in nursing students of UPN Veteran Jakarta.

\section{METHODS}

The type of research used is an analytic observational with a cross-sectional study design, an epidemiological study that studies the relationship of the independent variables, namely age, course load, and residence status, with the dependent variable, namely the level of academic stress students during the same period [12]. This research was conducted at the Faculty of Health Sciences at UPN Veteran Jakarta in July 2020. The population in this study were all students of the Undergraduate Nursing Study Program in 2019 and 2018, with a total sample of 175 students. The sampling method uses the accidental sampling technique. Data collection was carried out for 3 weeks using an online questionnaire via a

google form. Collecting data on the sample in the form of age, study load, and residence status used demographic data while on the level of academic stress, students used a modified DASS 42 instrument. Further data were analyzed by univariate and bivariate using the chi-square test $\alpha=0.05$.

\section{RESULT AND DISCUSSION}

Table. 1

\section{Respondent Characteristics}

Characteristics Frequency \%

\begin{tabular}{lcc}
\hline Gender & 20 & 11.4 \\
\hline Male & 155 & 88.6 \\
\cline { 1 - 1 } Female & & \\
\hline $15-20$ & 79 & 45.1 \\
\hline $21-25$ & 96 & 54.9 \\
\hline$>25$ & - & \\
\hline College Load & & \\
\hline Severe & 100 & 57.1 \\
\hline Moderate & 60 & 34.3 \\
\hline Mild & 15 & 8.6 \\
\hline
\end{tabular}




\section{Residence Status}

\begin{tabular}{lll}
\hline Boarding House & 25 & 14.3 \\
\hline Live with Parents & 150 & 85.7 \\
\hline Live with family & - & - \\
(husband/wife) & &
\end{tabular}

Academic Stress Levels

\begin{tabular}{lcc}
\hline Normal & 15 & 8.6 \\
\hline Mild & 25 & 14.3 \\
\hline Moderate & 60 & 34.3 \\
\hline Severe & 45 & 25.7 \\
\hline Very Severe & 30 & 17.1
\end{tabular}

Based on table 1 above, it is found that the majority of respondents are female as many as 155 people (88.6\%), Respondents who have severe college load are 100 people $(57.1 \%)$, the distribution of residence status of the majority of respondents with parents is 150 people $(85.7 \%)$, and the majority of respondents experience moderate stress, namely 60 people (14.3\%). Most respondents were aged $15-20$ years $(54.9 \%)$. The age group of respondents in this study entered the late adolescence, namely $15-20$ years. According to Jain \& Singhai [4] explains that in late adolescence, there is rapid mental development. Mental development in late adolescence also increases adolescents' ability to hypothesize anything related to their life and environment.

As students who have demands and obligations in the educational process, students must make adjustments or make adaptations used to cope with the changes that have occurred and are accepted during normal lectures in class or online system lectures during the COVID- pandemic. 19. The gender characteristics of the respondents indicated that the majority of respondents were female $(88.6 \%)$. The female respondents' dominant number is because the ratio between male and female students is more than a female. Female students also have to participate in various organizational activities or student activity units due to the limited number of male students. According to Karaman [7], explaining that if there is a dual role conflict between students that cannot be resolved with adaptive coping, then this can cause stress to students. The characteristics of the course load indicate that the highest percentage of respondents who experience stress due to massive academic factors $(57.1 \%)$. Students are required to have the ability to adapt the usual academic process in class to the online learning process, requiring students to get a lot of coursework from each lecturer per course, such as weekly quizzes, independent assignments, and group assignments. Completing assignments that require a short time so that students lack rest and harmony among members for group assignments can trigger stress in students.

The characteristics of student residence status indicate that most respondents live with their parents $(85.7 \%)$. Based on the regulations issued regarding the prevention of the spread of Covid-19, the entire academic process is carried out online. So that many students return to their hometowns, even though the majority live with parents of students, they are still required to adapt to the online learning process with the assigned workload. They must share roles in the family environment. The characteristics showed that the academic stress level of nursing students UPN Veteran Jakarta mostly experienced moderate stress levels $(34.3 \%)$. The level of student academic stress needs attention because students as of late teens have a high level of stress. High-stress conditions will result in students tend to get angry quickly and not focus on the learning process, and can trigger a person to behave negatively, such as smoking, consuming alcohol, fighting, free sex, and even drug use [6].

Table 2.

\section{Analysis of the Relationship between Age and Student Academic Stress Levels during the COVID-19} Pandemic

\begin{tabular}{|c|c|c|c|c|c|c|c|}
\hline \multirow{3}{*}{$\begin{array}{c}\text { Age } \\
\text { (Tahun) }\end{array}$} & \multicolumn{5}{|c|}{ Students Academic Stress Levels } & \multirow[b]{2}{*}{ Total } & \multirow{3}{*}{$P$ value } \\
\hline & Normal & Mild & Moderate & Severe & Very Severe & & \\
\hline & n $(\%)$ & n $(\%)$ & n $(\%)$ & n $(\%)$ & n $(\%)$ & $\mathbf{N}$ & \\
\hline \multirow[t]{2}{*}{$15-20$} & & & & & & & \\
\hline & $9(9.3)$ & 14(14.5) & 33(50) & $24(31.7)$ & $16(25.3)$ & 96 & \\
\hline
\end{tabular}




\begin{tabular}{|c|c|c|c|c|c|c|}
\hline $21-25$ & $6(7.29)$ & 11(10.4) & $27(21)$ & $21(21)$ & $14(10.41)$ & 79 \\
\hline$>25$ & & & & & & 0,001 \\
\hline
\end{tabular}

Table 2 shows the results of the analysis of the relationship between age and the level of academic stress in students. The results showed that most respondents experienced moderate academic stress as many as 33 people (50\%) at 15-20 years. The level of stress decreases as age increases. The results of statistical tests using the chi-square test obtained $\mathrm{p}$-value $=$ $0.001<0.05$. This shows a relationship between age and the level of academic stress in students during the COVID-19 pandemic. Nursing Science, the University of Indonesia, with a sample size of 93 students, found a difference in the proportion of the incidence of academic stress levels against age $(p=0.030)$ [9].the age level of students, the lower the academic stress level tends to be. This happens when someone is often exposed to the same stressor with the same pattern, so someone will get used to it and perceive the stressor as usual. With the same stressor, students can make acceptable adaptations so that as they age, they can control the level of academic stress.

Table 3.

\section{Analysis of the Relationship between College Load and Student Academic Stress Levels during the COVID-19 Pandemic}

\begin{tabular}{|c|c|c|c|c|c|c|c|}
\hline \multirow{3}{*}{$\begin{array}{c}\text { College } \\
\text { Load }\end{array}$} & \multicolumn{5}{|c|}{ Students Academic Stress Levels } & \multirow[b]{2}{*}{ Total } & \multirow{3}{*}{$P$ value } \\
\hline & Normal & Mild & Moderate & Severe & Very Severe & & \\
\hline & n $(\%)$ & n $(\%)$ & n $(\%)$ & n $(\%)$ & n $(\%)$ & $\mathbf{N}$ & \\
\hline Severe & $6(6)$ & 12(12) & 37(37) & $25(25)$ & $20(20)$ & 100 & \\
\hline Moderate & $9(15)$ & 11(18.3) & $16(27)$ & $15(25)$ & $8(15)$ & 60 & \\
\hline Mild & $\mathbf{0}$ & $2(13.3)$ & $9(53.3)$ & $4(26.7)$ & $2(6.7)$ & 15 & 0,045 \\
\hline
\end{tabular}

Table 3 shows the results of the analysis of the relationship between the course load and the level of student academic stress. The results of the study show that the highest percentage of respondents who experience stress due to severe academic factors with severe stress levels are 37 people $(37 \% \%)$ and respondents who experience stress due to moderate academic factors with moderate stress levels are 16 people $(27 \%)$. The results of statistical tests using the chi- square test obtained p-value $=0.045<0.05$ indicates a relationship between college load and the level of academic stress in nursing students at UPN Veteran Jakarta.Another study conducted on nursing students of STIKes Muhammadiyah Surakarta with a sample size of 63 students, found that the lecture schedule related to the lecture load affects the stress level of students $(p=0.041)$ [10].
Students with a severe college load can affect the level of student academic stress. This is because when data collection took place, learning was carried out online as an effort to prevent the spread of Covid-19 so that more student assignments for each lecturer per subject such as quizzes, independent assignments, and group assignments.

Piling up college assignments and a busy class schedule resulted in students having less time to rest so that it was easier to feel dizzy and often angry. In line with Smeltzer and Bare's theory in Karaman [7], if the body cannot adapt to changes in the environment, it can cause a disturbance in the body's balance so that it is easier to experience stress. 
Table 4

Analysis of the Relationship Between Residence Status and Student Academic Stress Levels

During the COVID-19 Pandemic

Students Academic Stress Levels

\begin{tabular}{lccccccc}
\multirow{2}{*}{ Residenec Status } & Normal & Mild & Moderate & Severe & Very Severe & Total & \multirow{2}{*}{ P value } \\
\cline { 2 - 7 } & $\mathbf{n}(\%)$ & $\mathbf{n}(\%)$ & $\mathbf{n}(\%)$ & $\mathbf{n}(\%)$ & $\mathbf{n}(\%)$ & $\mathbf{N}$ & \\
\hline Boarding house & $5(20)$ & $1(4)$ & $10(40)$ & $5(20)$ & $4(16)$ & 25 & \\
\hline Live with Parents & $10(6.7)$ & $24(16)$ & $50(33.3)$ & $40(26.7)$ & $26(17.3)$ & 150 & \\
\hline $\begin{array}{l}\text { Live with } \\
\text { family(husband/wife) }\end{array}$ & 0 & 0 & 0 & 0 & 0 & 0 & 0,166 \\
\hline
\end{tabular}

Table 4 shows the results of the analysis of the relationship between residence status and student academic stress levels. The results showed that most respondents lived with parents, namely 150 people $(85.7 \%)$, and among these respondents, most of them experienced moderate academic stress levels as many as 50 people $(33.3 \%)$. Of the 25 respondents who live in a boarding house or contract, ten people (40\%) experience moderate stress. It can be seen in the table that although most students live with their parents, there are still many students who experience moderate academic stress. The results of statistical tests using the chi-square test obtained p-value $=0.166>0.05$ indicate no relationship between residence status and academic stress levels in nursing students of UPN Veteran Jakarta. The results differed from the research conducted on the final year students of S1 Nursing at STIKES Widya Husada Semarang with a sample size of 76 students, found that there was a relationship between family factors and stress in final year students $(p=0.000)$ [11]. The study found that students' level of academic stress was influenced by the relationship between parents and children, parental support, and good communication with children. The results showed that although most students live with their parents, many students experience moderate to severe academic stress. This is because, during the online lectures implemented by UPN Veteran Jakarta, most students return to their hometowns, so,students are required to be adaptive to the online learning process with the assigned workload and have to share roles in the family environment. A person must control conflicts between academic assignments and family duties, if this conflict cannot be adequately resolved, then the conflict can cause stress to students.

\section{CONCLUSION}

Based on the results of the study regarding the factors related to the level of academic stress in nursing students of UPN Veteran Jakarta, it can be concluded that there is a relationship between age $(\mathrm{p}=0.001)$ and study load $(\mathrm{p}=0.045)$ with the level of academic stress in nursing students of UPN Veteran Jakarta. There is no relationship between residence status $(\mathrm{p}=0.166)$ with academic stress in nursing students of UPN Veteran Jakarta. It is hoped that further researchers will develop research related to visits to health services and financial conditions with student stress levels.

\section{REFERENCES}

[1] Kemendikbud, Surat Edaran Mendikbud No 36962/MPK.A/HK/2020 Kemenristekdikti, "Permenristek- dikti Nomor 44 Tahun 2015 tentang Standar Nasional Pendidikan Tinggi," Jakarta, 2015.

[2] M. G. Kadapatti and A. H. M. Vijayalaxmi, "Stressor of Academic Stress- A Study on PreUniversity Students," Indian J. . Sci. Res, vol. 3, no. 1, pp. 171-175, 2012.

[3] A.-M. Goff, "Stressors, Academic Performance, and Learned Resourcefulness in Baccalaureate Nursing Students," Int. J. Nurs. Educ.Scholarsh., vol. 8, no. 1, 2011.

[4] G. Jain and M. Singhai, "Academic stress amongst students: A review of literature," Prestig. e-Journal Manag. Res., vol. 4, no. 2, pp. 58-67, 2017. 
[5] K. J. Reddy, K. R. Menon, and A. Thattil, "Academic stress and its sources among university students," Biomed. Pharmacol. J., vol. 11, no. 1, pp. 531-537, 2018, doi: 10.13005/bpj/1404.

[6] M. A. Karaman, E. Lerma, J. C. Vela, and J. C. Watson, "Predictors of Academic Stress Among College Students," J. Coll. Couns., vol. 22, no. 1, pp. 41-55, 2019, doi: 10.1002/jocc.1211

[7] E. R. Ira Suwartika, Agus Nurdin, "Analisis Faktor yang Berhubungan dengan Tingkat Stress Akademik Mahasiswa Reguler Program Studi DIII Keperawatan Cirebon Poltekkes Kemenkes Tasikmalaya," J. Keperawatan Soedirman, vol. 9 , no. 3, pp. 173-189, 2014.

[8] S. Purwati, “Tingkat Stres Akademik pada Mahasiswa Reguler Angkatan 2010 Fakultas Ilmu Keperawatan Universitas Indonesia," Universitas Indonesia, 2012.

[9] I. Mardiati, F. Hidayatullah, and C. Aminoto, "Faktor eksternal tingkat stres mahasiswa keperawatan dalam adaptasi proses pembelajaran," 7th Univ. Res. Colloqium 2018 STIKES PKU Muhammadiyah Surakarta, pp. 172-181, 2018.

[10] O. T. Dwi Retnaningsih, Khusnul Aini, "Faktor-faktor yang berhubungan dengan stres pada mahasiswa tingkat akhir S1 Ilmu Keperawatan di STIKES Widya Husada Semarang," J. Ners Widya Husada Semarang, vol. 2, no. 1, 2018.

[11] S. Notoatmodjo, Metode Penelitian Kesehatan. Yogyakarta: Rineka Cipta. 